PressAcademia Procedia

\title{
PUBLIC FINANCE IN JORDAN: A LESSON FROM COVID-19
}

\author{
DOI: 10.17261/Pressacademia.2020.1346 \\ PAP- V.12-2020(10)-p.46-49
}

Muhanned Obeidat ${ }^{1}$, Ahmad Tarawneh ${ }^{2}$, Mohammad Khataybeh ${ }^{3}$, Ghassan Omet $^{4}$

${ }^{1}$ University of Jordan, Department of Finance, Amman, Jordan. mu.obeidat@ju.edu.jo, ORCID:0000-0002-8988-1291

2 University of Jordan, Department of Finance, Amman, Jordan. ah.altarawneh@ju.edu.jo, ORCID:0000-0002-5833-1887

${ }_{3}^{3}$ University of Jordan, Department of Finance, Amman, Jordan. khataybeh@ju.edu.jo, ORCID:0000-0003-3599-903X

${ }^{4}$ University of Jordan, Department of Finance, Amman, Jordan. gomet@ju.edu.jo, ORCID:0000-0002-8988-1387

To cite this document

Obeidat, M., Tarawnet, A., Khataybeh, M., Omet, G., (2020). Public finance in Jordan: a lesson from Covid-19. PressAcademia Procedia (PAP), V.12, p.46-49.

Permanent link to this document: $h$ ttp://doi.org/10.17261/Pressacademia.2020.1346

Copyright: Published by PressAcademia and limited licensed re-use rights only.

\section{ABSTRACT}

Purpose - COVID-19 is a human and economic tragedy. It has become obvious that the virus pressed hard public finances all over the world. However, countries with relatively limited fiscal space face will experience more pressure. Within this context, this paper has two objectives. First, to outline the status of public finance in Jordan, and in particular, the weight that foreign grants carry in public revenues. Second, to examine the impact of foreign grants on the tax effort in Jordan. In other words, the objective is to examine whether or not public finance in Jordan suffers from the "aid curse".

Methodology - The period 1984 - 2019 forms the data for the statistical analysis. In addition, and to examine the impact of foreign aid on tax effort, the paper uses time series analysis techniques including stationarity tests, optimal lag length criteria, co-integration, long-run relationship, and variance decomposition analysis.

Findings - Based on the empirical results, Jordan does suffer from the curse of aid. Grants do have a negative and significant impact of tax revenues (tax effort).

Conclusion - Relevant stakeholders in Jordan should use COVID-19 as a "trigger" point for change in the country's fiscal mobilization process. This is the only way to reduce the growing public debt, and reduce the country's reliance on foreign grants.

Keywords: Jordan, fiscal space, grants, cures of aid, co-integration.

JEL Codes: H30; H6O; H62

\section{INTRODUCTION}

COVID-19 has forced governments to introduce various fiscal measures. Within this context, however, countries with limited fiscal space will experience two problems. First, their budget deficits will increase as their public spending increases and local revenues fall. Second, the increasing budget deficits will increase public debt levels.

COVID-19 is a tragedy. However, the evolving experience of COVID-19 should be a "trigger" that creates future windfalls. For example, all previous Jordanian governments (since availability of data in 1965) have had four common themes. They all had relatively low tax effort, consistent budget deficits, consistence reliance on foreign grants, and high public debt. During the period 2010-2019, for example, the mean annual tax revenue to Gross Domestic Product (GDP) was around the 15 percent mark, budget deficit to GDP ratio was equal to -7.5 percent, mean annual grants to GDP ratio was equal to 2.9 percent, and public debt to GDP ratio was equal to 84.7 percent. Based on just these four public finance observations, one can argue that COVID-19 provides Jordan with an opportunity for change. Indeed, public finance in Jordan might suffer from the Dutch Disease. All previous, and present, governments have received huge amounts of grants. Over time, this windfall has probably contributed to the low tax effort.

This paper has two objectives. First, to describe the status of public finance in general, and the tax effort in particular. Second, to examine the impact of foreign grants on Jordan's tax effort. Section 2 provides a brief review of the relevant literature. Section 3 outlines the data and methodology. In section4, we present the main results and discuss them. Finally, section 5 concludes the paper. 


\section{AID AND TAX REVENUE: LITERATURE REVIEW}

The absence of a theoretical model notwithstanding, the literature points out that grants can encourage the recipient economies to improve their tax and collection systems, and hence, increase their tax effort. However, grants can also make governments less prepared to increase their tax efforts (McGillivray and Morrissey, 2001 and Carter, 2013). The empirical literature that examines the grants-tax effort nexus is in disagreement. Some papers report a positive impact of grants on tax revenues. Others, however, report either a negative impact or no relationship at all.

Some of the papers that report a positive impact of grants on tax revenues are Heller (1975), Remmer (2004), Clist and Morrisey (2011), and Carter (2013). For example, Clist and Morrisey (2011) examine the tax effort in 82 developing countries (1970-2005), and based on their results, the impact of grants on tax revenue is positive and tends to "increase tax revenue over the medium term". Amusa et al. (2020) use the autoregressive distributed lag model approach (ARDL) to examine the impact of foreign aid on the tax effort in Nigeria. Their results reflect a positive impact.

Those with a negative impact include Gupta (2007), Moss et al. (2008), Benedek et al. (2012), and Boukbech et al. (2018). For example, Boukbech et al (2018) examine the impact of grants on the tax effort for a panel 29 lower middle-income countries (2001-2014). Again, their results indicate that net official development aid negatively impacts the tax effort.

In addition to the impact of grants on tax effort, the research literature looks at other determinants of tax revenues. For example, the fact that the agriculture sector is difficult to tax (high informal sector), one expects a negative relationship between the share of agriculture in GDP and total tax effort (Morrissey et al. (2015). In addition, in economies with large manufacturing companies, tax revenues are usually higher than in other economies with no such sector (Fenochietto and Pessino, 2013). Real economic growth is also an important factor. Growth should positively affect tax revenues. Many researchers use other variables as well, including, for example, government stability and law and order (Gupta, 2007). Rodríguez (2018) used a dataset that includes 138 countries (1976-2015) to estimate static and dynamic models. The results indicate that the share of the agriculture sector in countries' GDP, financial intermediation, natural rents, education, and the quality of government and democracy impact tax revenues.

Finally, it is interesting to note that in a recently published paper, Oz-Yalaman (2019) examine the impact of financial inclusion on the tax effort in 137 countries across the globe. Using panel data analysis and the Global Findex database (2011-2017), the results show that there is a positive relationship between financial inclusion and tax revenues.

\section{THE DATA AND METHODOLOGY}

To examine the impact of foreign grants on the tax effort in Jordan, we specify the below model:

$\mathrm{TE}_{\mathrm{t}}=\lambda+\beta \mathrm{GRANTS}_{\mathrm{t}}+\psi \mathrm{GDP}+\varepsilon_{\mathrm{t}}$

where, TE, GRANTS, and GDP are the natural logarithm of tax revenues, received grants, and real GDP respectively. The expected signs of the parameters are $\lambda>0, \beta>0, \psi>0$. The error term $(\varepsilon)$ is assumed to be independently and identically distributed. Finally, the subscript (t) denotes time (1984-2019).

To estimate expression 1, we examine the data in terms of their stationarity. We then examine the optimal lag structure and estimate the co-integrating relationship among the variables using the Johansen-Masulius procedure. In other words, the co-integrating rank ( $r$ ) is tested using the maximum eigenvalue and the trace test. Based on the co-integration results, a vector error-correction (VEC) model is estimated to examine the long-run and short-run causality dynamics.

$\Delta \mathrm{TE}_{\mathrm{t}}=\alpha+\lambda e_{\mathrm{t}-1}+\sum_{i=1}^{n} b \mathrm{i} \Delta \mathrm{GRANTS}_{\mathrm{t}-\mathrm{i}}+\sum_{i=1}^{m} c \mathrm{i} \Delta \mathrm{GDP}_{\mathrm{t}-\mathrm{i}}+\varepsilon_{\mathrm{t}}$

In this expression (2), a long-run convergence does occur between the variables if the error correction term $(\lambda)$ is negative and statistically significant. Finally, we estimate variance decomposition analysis to examine the power of grants and GDP in explaining the variability of tax effort over time.

\section{FINDINGS AND DISCUSSION}

Before we present and discuss the results, it is useful to raise some observations about public finance in Jordan. First, the tax effort remains relatively low. During the period $1965-2019$, tax to GDP ratio has increased from 7.7 percent to 15.1 percent only.

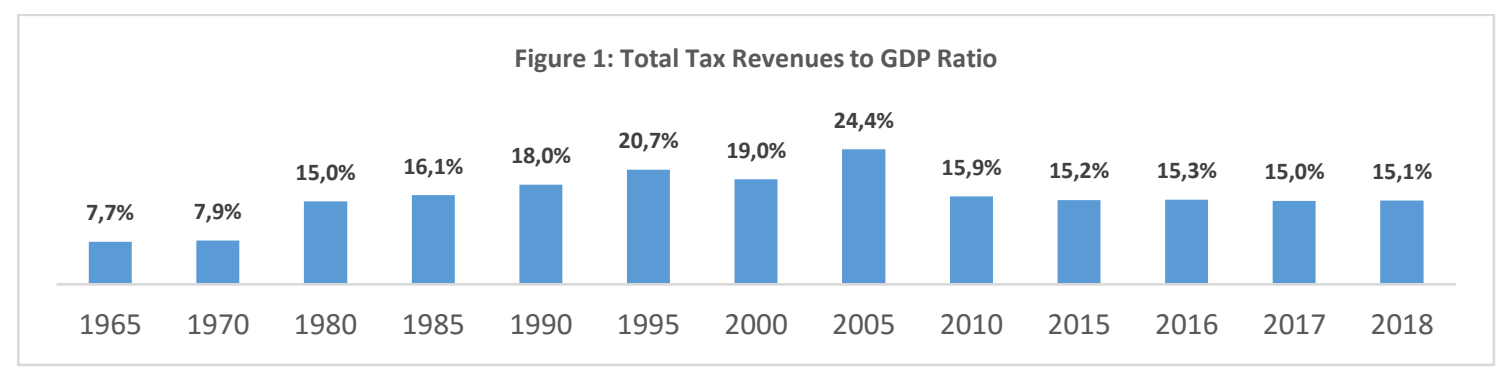


Second, since the year 1965, no government has ever experience a surplus in its budget. Indeed, during the period 1976 -1980, the mean annual budget deficit to GDP ratio was more than 22 percent (Table 1). Third, grants have always been a major part of the government's local revenues (tax and non-tax). Again, during the period 1968 - 1970, the mean annual ratio of grants to total public revenues was equal to $115.2 \%$. However, since then, grants to public revenues have been falling.

Table 1: Public Finance and Grants

\begin{tabular}{|l|c|c|c|c|c|}
\hline Period & $\begin{array}{c}\text { Budget Deficit to } \\
\text { GDP }\end{array}$ & $\begin{array}{c}\text { Grants to Local } \\
\text { Revenues }\end{array}$ & Period & $\begin{array}{c}\text { Budget Deficit to } \\
\text { GDP }\end{array}$ & $\begin{array}{c}\text { Grants to Local } \\
\text { Revenues }\end{array}$ \\
\hline $1965-1967$ & $-8.2 \%$ & $54.8 \%$ & $1991-1995$ & $-5.2 \%$ & $16.9 \%$ \\
\hline $1968-1970$ & $-21.8 \%$ & $115.2 \%$ & $1996-2000$ & $-6.1 \%$ & $13.5 \%$ \\
\hline $1971-1975$ & $-17.1 \%$ & $101.5 \%$ & $2001-2005$ & $-7.3 \%$ & $23.3 \%$ \\
\hline $1976-1980$ & $-22.2 \%$ & $86.5 \%$ & $2006-2010$ & $-6.5 \%$ & $12.6 \%$ \\
\hline $1981-1985$ & $-16.9 \%$ & $57.3 \%$ & $2011-2015$ & $-8.5 \%$ & $15.7 \%$ \\
\hline $1986-1990$ & $-15.0 \%$ & $32.6 \%$ & $2016-2019$ & $-5.6 \%$ & $13.0 \%$ \\
\hline
\end{tabular}

In Table 2, we present the results of the unit root test (Dickey-Fuller). These results reveal that all variables are non-stationary at their level forms and stationary at their first differences forms. Indeed, this result is consistent in all three estimations: with no constant and trend, with a constant and no trend, and with both a constant and trend.

Table 2: Augmented Dickey-Fuller Unit Root Test

\begin{tabular}{|l|c|c|c|c|c|c|}
\hline Variable & \multicolumn{3}{|c|}{ Level } & \multicolumn{3}{c|}{ First-Difference } \\
\hline & None & Constant & Constant \& Trend & None & Constant & Constant \& Trend \\
\hline TAX & 5.981 & -0.485 & -2.369 & $-3.421^{*}$ & $-5.225^{*}$ & $-5.139^{*}$ \\
\hline GRANTS & 1.328 & 0.187 & -2.540 & $-7.377^{*}$ & $-7.583^{*}$ & $-7.849^{*}$ \\
\hline GDP & 5.661 & 0.718 & -2.045 & $-3.586^{*}$ & $-5.149^{*}$ & $-5.275^{*}$ \\
\hline *Significant at the 99 percent confidence level.
\end{tabular}

The stationarity findings imply that all variables are integrated in the same order (first differences). Indeed, this conclusion is supported by the Phillips-Peron test. In addition, this conclusion indicates that we can apply the Johansen co-integration test to test or detect the longterm co-integrating relationship among our group of variables. With an optimal lag length equal to 2, in Tables 3 and 4 , we report the results of the Johansen co-integration test.

Table 3: Johansen Multivariate Co-Integration Test

\begin{tabular}{|c|c|c|c|c|}
\hline $\begin{array}{c}\text { Hypothesized No. of } \\
\text { CE(s) }\end{array}$ & Eigen Value & Trace Statistic & 5 percent CV & P-Value \\
\hline None ${ }^{*}$ & 0.527 & 34.988 & 29.798 & 0.012 \\
\hline At most 1 & 0.226 & 9.544 & 15.495 & 0.317 \\
\hline
\end{tabular}

Table 4: Johansen Multivariate Co-Integration Test

\begin{tabular}{|c|c|c|c|c|}
\hline Hypothesized No. of CE(s) & Eigen Value & Trace Statistic & 5 percent $\mathrm{CV}$ & P-Value \\
\hline None ${ }^{*}$ & 0.527 & 25.443 & 21.132 & 0.0116 \\
\hline At most 1 & 0.226 & 8.699 & 14.264 & 0.3120 \\
\hline At most 2 & 0.025 & 0.845 & 3.8415 & 0.3579 \\
\hline
\end{tabular}

Again, based on the reported results of both the trace and maximum eigenvalue statistics, we conclude that there is at least two cointegrating relationships at the 5 percent significance level. Such results reveal the presence of a long-run relationship among our group of variables. In addition, this result implies that we can estimate a Vector Error Correction Model (VEC).

The regression results under the VEC model with two lags confirm the existence of a long-run equilibrium relationship among our variables. Indeed, this is confirmed by the negative and significant value of the coefficient $(\lambda)$ of the error correction term $(\lambda$ et- 1$)$.

Long Run Relationship : $\mathrm{TAX}_{\mathrm{t}-1}=49.241-2.381 *$ Grants $+4.976 * \mathrm{GDP}$

Finally, it is also useful to note that the results of the variance decomposition analysis reveal that the variability in real economic growth is largely lagged by its own variance. The results of this analysis are reported in Table 5 below. However, what is more important to note is the observation that grants reflect the stronger power in explaining the variability in tax revenue over time. 
Table 5 : Variance Decomposition Analysis

\begin{tabular}{|c|c|c|c|}
\hline Period & TAX EFFORT & GRANTS & GDP \\
\hline 1 & 100.0000 & 0.000000 & 0.000000 \\
\hline 2 & 80.69828 & 15.93966 & 3.362069 \\
\hline 3 & 68.04761 & 27.50266 & 4.449725 \\
\hline 4 & 65.82101 & 29.47771 & 4.701278 \\
\hline 5 & 65.04645 & 30.04461 & 4.908937 \\
\hline 6 & 64.23717 & 30.69906 & 5.063773 \\
\hline 7 & 63.67549 & 31.16794 & 5.156568 \\
\hline 8 & 63.32255 & 31.45563 & 5.221825 \\
\hline 9 & 63.04943 & 31.67696 & 5.273605 \\
\hline 10 & 62.82696 & 31.85885 & 5.314188 \\
\hline
\end{tabular}

\section{CONCLUSIONS}

COVID-19 will widen budget deficits, especially in countries with limited fiscal space. Within this context, one can argue that the public finance implication of the corona should be used by countries as a "trigger" point for change. The fact that the Jordanian economy has low tax revenues and dependent on foreign grants, this paper examined the nexus between tax revenues and grants during the period $1980-2019$. Clearly, the results indicate that foreign aid negatively and significantly decreases tax revenues. Jordan suffer from the "curse of aid" or "Dutch Disease". Relevant stakeholders in Jordan to change the tax law in Jordan, make its fair, progressive, diversified, and simple. This is the only way to reduce the growing public debt, and reduce the country's reliance on foreign grants.

\section{REFERENCES}

Amusa K., N. Monkam \& N. Viegi (2020). Can foreign aid enhance domestic resource mobilization in Nigeria? Journal of Contemporary African Studies, 38: 294309.

Benedek, D., E. Crivelli, S. Gupta and P. Muthoora (2012). Foreign aid and revenue: Still a crowding out effect? Public Finance Analysis, 70: 67-96.

Boukbech, R., A. Bousselhamia, and E. Elhadj (2018). Determinants of tax revenues: Evidence from a sample of Lower Middle Income countries. Applied Economics and Finance, 6: 11-20.

Carter, P. (2013). Does foreign aid displace domestic taxation? Journal of Globalization and Development 4: pp. 1-47.

Clist, P. and O. Morrissey (2011). Aid and tax revenue: Signs of a positive effect since the 1980s. Journal of International Development 23: 165-80.

Fenochietto, R. and C. Pessino (2016). Understanding countries' tax effort. IMF Working Paper No. 13/42.

Gupta, A. (2007). Determinants of tax revenue efforts in developing countries. IMF Working Paper No. 07/184.

Heller, P. (1975). A model of public fiscal Behavior in developing countries: Aid, investment and taxation. American Economic Review, June: $429-445$.

McGillivray, M and O. Morrissey (2001). New of evidence of the fiscal effects of aid, CREDIT Research Paper, No. 01/13, Centre for Research in Economic Development and International Trade, University of Nottingham, Nottingham.

Morrissey, O. (2015). Fiscal composition and aid effectiveness: A political economy model. World Development, 69: 106-115.

Moss, T., G. Pettersson and N. van de Walle (2008). An aid-institutions paradox? A review essay on aid ependency and Stsate building in Sub-Saharan Africa, in Reinventing Aid, ed., W. Easterly, Cambridge MA: The MIT Press.

Oz-Yalaman, G. (2019). Financial inclusion and tax revenue. Central Bank Review, 19: 107-113

Remmer, K. (2004). Does foreign aid promote the expansion of government? American Journal of Political Science 48: 77-92. 